\title{
Legislative organization and executive success rate at the subnational level: a comparison of Brazil and Germany, 1990-2010
}

\author{
Bernd Weber | PhD Candidate and Lecturer in Politics and International \\ Relations at Sciences Po Paris| bernd.weber@sciencespo.fr \\ Sérgio Praça | Adjunct Professor of Public Policy, Universidade Federal do ABC | \\ sergio.praca@ufabc.edu.br
}

\begin{abstract}
How does parliamentary organization affect the legislative success rate of the executive in presidential and parliamentary systems at the subnational level? Why are some governors much more successful than others even though they serve under the same basic constitutional designs? This essay explores these questions with a comparison of Brazilian and German states from 1990 to 2010. Our main findings are that governors' success rates in both Brazil and Germany seem not to be associated with centralization of legislative institutions. This means that coalition management and party politics may play a larger role than expected by the literature. Other factors, such as "minor" and neglected legislative arrangements can compound the governors' strength and allow them to reach Westminster levels of legislative success.
\end{abstract}

I How does parliamentary organization affect the legislative success rate of the executive in presidential and parliamentary systems at the subnational level? Why are some governors much more successful than others even though they serve under the same basic constitutional designs? Furthermore, why are some governors much more successful than the literature expects? This article explores these three questions with a comparison of Brazilian and German states from 1990 to 2010.

We argue that legislative organization plays a central role in explaining why some Brazilian and German governors are much more successful in the approval of their bills than others. There is a burgeoning literature on this matter in both presidential systems (Figueiredo and Limongi 2000) and parliamentary democracies (Doring and Hallerberg 2004). We contribute to this literature in at least two ways.

The first is a novel comparison between multiparty systems with very different "basic institutions" i. e., systems of government and electoral systems. ${ }^{1}$
We believe that the fact Brazil and Germany both have considerable legislative fragmentation and diversity in party ideology makes a comparison between these countries very promising.

Our second possible contribution is in the unpacking of the "minor" legislative rules that may have considerable, though indirect, impact on policy. Though much has been written about negative agenda power (Cameron 2000), positive agenda power (Carey and Shugart 1998) and how they interact (Cox 2000, 2006), attention is still lacking as to the effects of seemingly "minor" institutions.

The literature expects constitutional design, party politics and legislative organization to explain the success rate of the executive. Our case studies allow us to hold the first set of variables constant when we compare Brazilian states to Brazilian states. The second set of variables - related to party politics are held constant when we compare some Brazilian states to some German states. And finally, the "legislative organization" variable is conceptualized 
considering which actors hold negative and positive agenda power and is held constant when comparing some Brazilian states to some German states.

We dialogue with three strands of the literature in political science. The first strand is comprised of many authors that attempt to explain executive success through classic constitutional variables such as the existence of a vote of confidence procedure, the existence of presidential agenda power entrenched in the Constitution and the importance of electoral system incentives (Mainwaring and Shugart 1997; many others). The second strand also focuses on constitutional institutions, but with a clear incorporation of coalition government and party politics as the main explanatory variable for executive success (Strom et al. 2010; Saiegh 2009; many others). Finally, the third strand in the literature incorporates matters of legislative organization, something which is particularly innovative for presidential systems (Strom 1998; Cox 2000; Figueiredo and Limongi 2000; Döring 2001; many others).

Before getting into the theoretical discussion, we note that our main puzzle - Why are most governors of Brazilian and German states more successful in the legislature than the literature expects? - must be illustrated with data about legislative success. Table 1 presents this for Brazilian governors and Table 2 does the same for German governors.

Table 1. Government Success Rates in the Brazilian States, 1987 to 2008

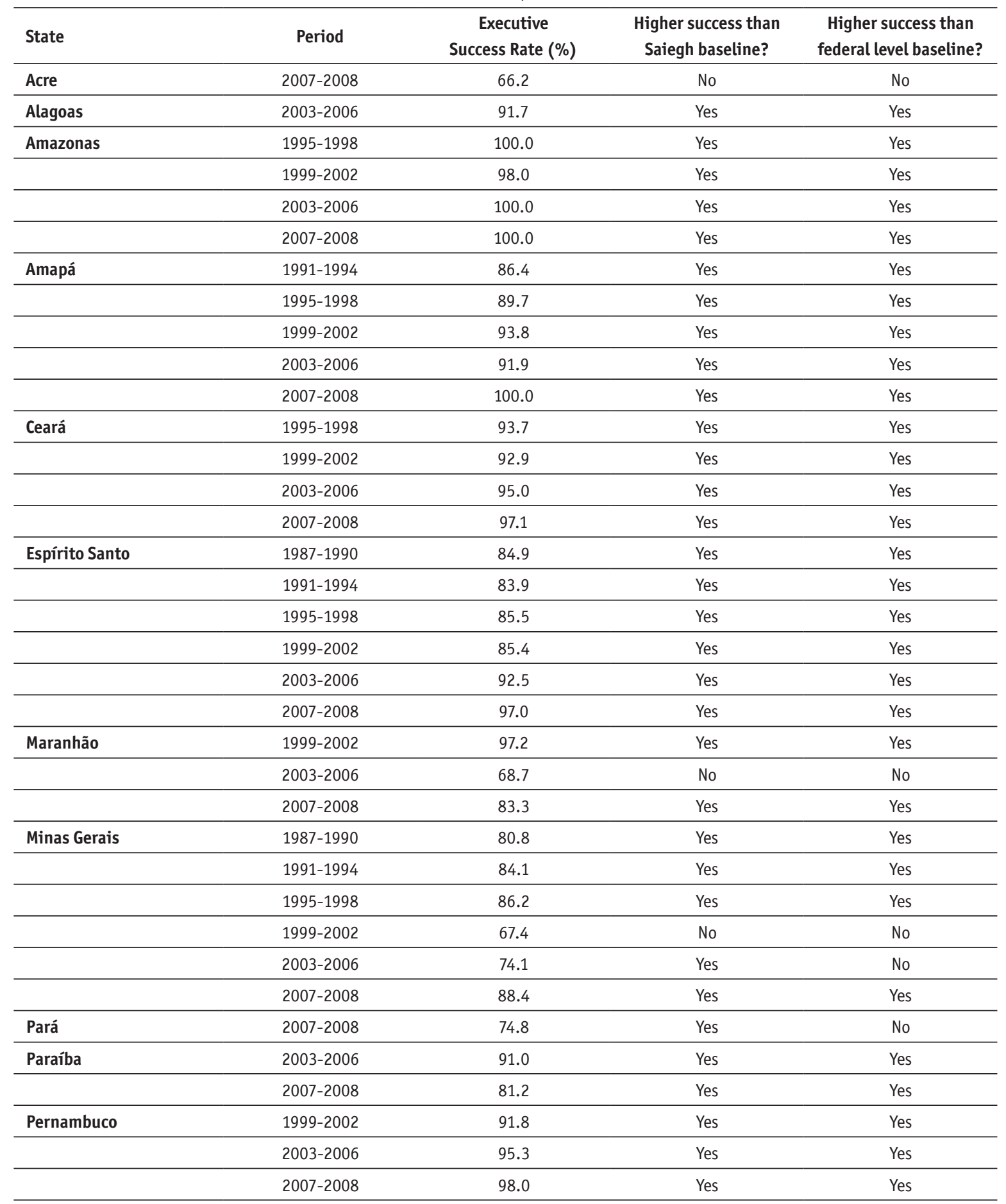




\begin{tabular}{|c|c|c|c|c|}
\hline State & Period & $\begin{array}{c}\text { Executive } \\
\text { Success Rate (\%) }\end{array}$ & $\begin{array}{l}\text { Higher success than } \\
\text { Saiegh baseline? }\end{array}$ & $\begin{array}{l}\text { Higher success than } \\
\text { federal level baseline? }\end{array}$ \\
\hline \multirow[t]{4}{*}{ Paraná } & 1995-1998 & 92.9 & Yes & Yes \\
\hline & $1999-2002$ & 81.1 & Yes & Yes \\
\hline & 2003-2006 & 91.4 & Yes & Yes \\
\hline & $2007-2008$ & 86.9 & Yes & Yes \\
\hline \multirow[t]{3}{*}{ Rio de Janeiro } & 1995-1998 & 90.9 & Yes & Yes \\
\hline & $1999-2002$ & 78.0 & Yes & Yes \\
\hline & $2003-2006$ & 82.7 & Yes & Yes \\
\hline \multirow[t]{5}{*}{ Rio Grande do Sul } & 1991-1994 & 76.9 & Yes & Yes \\
\hline & 1995-1998 & 91.5 & Yes & Yes \\
\hline & 1999-2002 & 78.3 & Yes & Yes \\
\hline & $2003-2006$ & 91.0 & Yes & Yes \\
\hline & $2007-2008$ & 92.1 & Yes & Yes \\
\hline \multirow[t]{4}{*}{ Santa Catarina } & $1995-1998$ & 90.1 & Yes & Yes \\
\hline & 1999-2002 & 91.9 & Yes & Yes \\
\hline & $2003-2006$ & 93.6 & Yes & Yes \\
\hline & $2007-2008$ & 92.2 & Yes & Yes \\
\hline \multirow[t]{3}{*}{ Sergipe } & 1999-2002 & 84.7 & Yes & Yes \\
\hline & $2003-2006$ & 92.6 & Yes & Yes \\
\hline & $2007-2008$ & 79.2 & Yes & Yes \\
\hline \multirow[t]{6}{*}{ São Paulo } & $1987-1990$ & 76.5 & Yes & No \\
\hline & 1991-1994 & 60.7 & No & No \\
\hline & $1995-1998$ & 90.4 & Yes & Yes \\
\hline & 1999-2002 & 75.3 & Yes & No \\
\hline & $2003-2006$ & 79.6 & Yes & Yes \\
\hline & $2007-2008$ & 99.1 & Yes & Yes \\
\hline Total & & 84.4 & Yes & Yes \\
\hline
\end{tabular}

Source: Tomio and Ricci (2010); the Saiegh (2009) baseline is 66\%; Federal level baseline is $75 \%$.

Table 2. Government Success Rates in the German States, 1990 to 2011

\begin{tabular}{|c|c|c|c|c|}
\hline State & Period & $\begin{array}{c}\text { Executive } \\
\text { Success Rate(\%) }\end{array}$ & $\begin{array}{l}\text { Higher success than } \\
\text { Saiegh baseline? }\end{array}$ & $\begin{array}{l}\text { Higher success } \\
\text { than federal } \\
\text { level baseline? }\end{array}$ \\
\hline \multirow[t]{3}{*}{ Bayern } & 1994-1998 & 100.00 & Yes & Yes \\
\hline & $1998-2003$ & 99.12 & Yes & Yes \\
\hline & $2003-2008$ & 100.00 & Yes & Yes \\
\hline \multirow[t]{3}{*}{ Brandenburg } & 1994-1999 & 99.30 & Yes & Yes \\
\hline & $1999-2004$ & 98.54 & Yes & Yes \\
\hline & 2004-2009 & 100.00 & Yes & Yes \\
\hline \multirow[t]{4}{*}{ Hamburg } & $1997-2001$ & 97.20 & Yes & Yes \\
\hline & 2001-2004 & 97.06 & Yes & Yes \\
\hline & $2004-2008$ & 100.00 & Yes & Yes \\
\hline & 2008-2011 & 96.40 & Yes & Yes \\
\hline \multirow[t]{3}{*}{ Hessen } & 1995-1999 & 96.63 & Yes & Yes \\
\hline & $1999-2003$ & 98.96 & Yes & Yes \\
\hline & $2003-2008$ & 100.00 & Yes & Yes \\
\hline \multirow[t]{4}{*}{ Mecklenburg-Vorpommern } & 1990-1994 & 95.32 & Yes & Yes \\
\hline & 1994-1998 & 95.91 & Yes & Yes \\
\hline & $1998-2002$ & 97.18 & Yes & Yes \\
\hline & $2002-2006$ & 98.88 & Yes & Yes \\
\hline \multirow[t]{3}{*}{ Niedersachsen } & 1994-1998 & 98.25 & Yes & Yes \\
\hline & $1998-2003$ & 97.83 & Yes & Yes \\
\hline & $2003-2008$ & 97.81 & Yes & Yes \\
\hline
\end{tabular}




\begin{tabular}{|c|c|c|c|c|}
\hline State & Period & $\begin{array}{c}\text { Executive } \\
\text { Success Rate(\%) }\end{array}$ & $\begin{array}{l}\text { Higher success than } \\
\text { Saiegh baseline? }\end{array}$ & $\begin{array}{l}\text { Higher success } \\
\text { than federal } \\
\text { level baseline? }\end{array}$ \\
\hline \multirow[t]{3}{*}{ Nordrhein-Westfalen } & $1995-2000$ & 100.00 & Yes & Yes \\
\hline & $2000-2005$ & 100.00 & Yes & Yes \\
\hline & $2005-2010$ & 99.47 & Yes & Yes \\
\hline \multirow[t]{3}{*}{ Rheinland-Pfalz } & 1991-1996 & 99.12 & Yes & Yes \\
\hline & $1996-2001$ & 100.00 & Yes & Yes \\
\hline & $2001-2006$ & 100.00 & Yes & Yes \\
\hline \multirow[t]{3}{*}{ Saarland } & 1994-1999 & 86.84 & Yes & Yes \\
\hline & $1999-2004$ & 100.00 & Yes & Yes \\
\hline & 2004-2009 & 99.12 & Yes & Yes \\
\hline \multirow[t]{4}{*}{ Sachsen } & 1990-1994 & 98.25 & Yes & Yes \\
\hline & 1994-1999 & 98.51 & Yes & Yes \\
\hline & 1999-2004 & 95.65 & Yes & Yes \\
\hline & 2004-2009 & 93.07 & Yes & Yes \\
\hline \multirow[t]{3}{*}{ Sachsen-Anhalt } & 1994-1998 & 92.39 & Yes & Yes \\
\hline & $1998-2002$ & 97.26 & Yes & Yes \\
\hline & $2002-2006$ & 99.15 & Yes & Yes \\
\hline \multirow[t]{3}{*}{ Schleswig-Holstein } & 1992-1996 & 100.00 & Yes & Yes \\
\hline & $1996-2000$ & 97.22 & Yes & Yes \\
\hline & $2000-2005$ & 93.75 & Yes & Yes \\
\hline \multirow[t]{4}{*}{ Thüringen } & 1990-1994 & 96.60 & Yes & Yes \\
\hline & 1994-1999 & 97.52 & Yes & Yes \\
\hline & 1999-2004 & 94.44 & Yes & Yes \\
\hline & 2004-2009 & 97.30 & Yes & Yes \\
\hline
\end{tabular}

Source: Authors' calculations based on statistics provided by the Landtag administrations for each legislative period; the Saiegh (2009) baseline is $66 \%$; Federal level baseline is $75 \%$.

The rest of the article is divided into five sections. The first introduces the three main models in legislative studies that guide our theoretical approach and on which we base our legislative centralization index. The second section presents the two main puzzles regarding legislative organization and executive success rates in Brazil and Germany. The third section explains our legislative centralization index and the fourth presents our results for Germany and Brazil. Section five concludes.

\section{(I) Three schools of legislative studies}

Legislatures are complex political institutions that constitute an arena where members compete for valuable resources, which are legislative time, institutional positions, staff and funding and foremost legislative outcomes (McCubbins 2005). In order to explain the underlying organizational structures and processes leading to the outcomes, three different models have come to dominate the field of comparative legislative studies, which are the 'Pivotal Politics Model', 'Conditional Party Government Model', and 'Procedural Cartel Theory'. The main dividing line between them lies in the acceptance or denial of party dominance in the parliament, affecting the behavior of its members and thereby the legislative outcomes. While party dominance and discipline are widely taken for granted in Westminster-style legislatures like the British House of Commons (Cox 1987), they have been contested in the case of the U.S. Congress and Brazilian state legislatures. In the following we will briefly discuss the three influential models and their guiding theoretical assumptions, as well as their viability with regard to our Brazilian and German cases.

The 'Pivotal Politics Model' is mainly based on the work of Krehbiel $(1993,1995,1998)$ and is closely linked to the informational approach (Gilligan and Krehbiel $1987 ; 1989 ; 1990)$. It clearly states that legislative outcomes are based on the preferences of independent and fully strategic legislators and not on 'party influence'. The main rationale behind it is that legislative institutions and outcomes are adopted by majority rule, following a bargaining process between the individual legislators. But they reflect the preferences of the majority (i.e., the median legislator) and not of party-based coalitions. ${ }^{2}$ This implies 'weak parties' in legislative politics, but also in electoral politics vis-à-vis the legislators and their interest in reelection.

Does the model provide an accurate understanding of the state assemblies under investigation? This is hardly the case for the Landtage, since the German parties largely control the access of candi- 
dates to the ballot in the mixed election systems. To ignore the party preferences and 'voting discipline' (Fraktionsdisziplin) presents a serious threat to the reelection of a candidate, which is not the case in the U.S. Correspondingly, reelection in Germany is foremost a function of the partisan voting of the electorate (Eder and Magin 2008; Masicotte 2010). Likewise in Brazil, party bosses have formal and informal control over the electoral success of backbenchers (Braga and Praça 2007), despite assertions to the contrary by Mainwaring (1991) and Carey and Shugart (1995, p. 428).

Parallel to the informational model, other models have been developed that can be labeled as 'partisan theories' (Diermeier and Vlaicu 2011a), since they acknowledge party affiliation as main explaining variable of legislative outcomes. They can be distinguished by their understanding of parties as 'floor voting coalitions' or as 'procedural coalitions'. The floor-voting approach to parties assumes that legislative coalitions provide collective benefits that may conflict with individuals' interests, so that a collective action problem arises. In the 'Conditional Party Government Model' (Rhode 1991), party leaders can provide incentives to party members to overcome their opposition or to change their vote on policy issues. They can inter alia offer career opportunities, such as appointments to attractive party positions, committees or ministries, or use 'sticks' like the loss of institutional positions, or even denial of access to the ballot. The strength of this party government depends on party unity (often referred to as 'homogeneity') on the major legislative agenda and on the polarization between the party in government and the opposition. While the capacity to exert effective party pressure is completely rejected by the 'Pivotal Politics Model', the key issue of criticism on this partisan approach in the broader congressional studies debate is the problem of distinguishing the effects of members' interest and party affiliation (McCarty et al. 2001, Snyder and Groseclose 2000).

The model seems to be highly appropriate to frame the debate of German scholars on voting discipline versus free mandate (Arndt 1989) in a way to facilitate a broader, comparative and theoretically guided discussion (Saalfeld 2005). Indeed, parties provide the only channel for a political career in the Länder and the voting behavior can be sanctioned or rewarded through positive and negative conditionality. Besides party pressure, the system of parliamentary democracy enforces voting discipline, since the head of government can dissolve the parliament and impose a vote of confidence. Such constitutional rules increase the costs of deflecting voting behavior for backbenchers. Nevertheless, conflicts between the government, party leaders and backbenchers can occur due a lack of homogeneity in the governing party or the governing party coalition, a strong committee orientation of legislators as members of a highly specialized working parliament (Arbeitsparlament), or because of a lack of interest in a parlia- mentary career (Saalfeld 2005, 30f). In Brazil, the idea of parties as "floor voting coalitions" instead of agenda setters in earlier stages of the legislative process has been convincingly put to rest, at least at the national level, by Amorim Neto et al. (2003).

The second 'partisan approach' defines parties as 'procedural coalitions'. The central issue is the ability of the governing party to control the legislative agenda, i.e., the set of bills considered and voted on the floor (Cox and McCubbins 2005, p. 19). Instead of exerting pressure on its members, the party leaders take control of procedures and influence the agenda. The aforementioned theoretical and empirical problem of identifying party influence and its effects is reframed in terms of an agenda control problem. Even though Krehbiel (1995) tries to provide empirical evidence against party influence on legislative institutions in the context of the U.S. Congress, there is evidence that the majority party uses restrictive rules in partisan affairs, disadvantaging the minority (Cox 2000; McCubbins 2005).

The 'Procedural Cartel Theory' of Cox and McCubbins (2005) bridges the gap between 'partisan theories' and the 'Pivotal Politics Model', since it combines the behavioral premise of unconstrained legislators that do not agree on issues along party lines, with parties exerting control on issues to be voted on. In this context, the governing parties form a 'cartel' by using the rule-making power of the assembly to bias the legislative process in their favor. Such a 'cartel' can emerge since the party leaders can provide a persuasive collective good to party members and backbenchers, which is the party's reputation with the electorate. Since open conflict is often seen as 'admission of failure' (Cowley 2002, p. 179), it is important for the parties to keep controversial and dividing issues off the floor. Control of the legislative procedures by positive and negative agenda-setting power provides party leaders with the ability to exert subtle strategic influence on the legislative process in order to reach preferred outcomes. This rationale is easily extended to the Brazilian case.

Controversial issues can harm the multiparty-coalitions in the Länder severely, as they did at the national level, once they reach the floor (Meng 2002), especially since some of the coalitions are considered to be more heterogeneous. This makes an investigation of the procedural cartel in Brazil and German states even more pertinent.

\section{(II) Presenting the puzzles}

\section{Puzzle 1: Why are the executive success rates in the Länder as high as one would expect them to be in a Westminster-style parliamentary system?}

Any judgment of how successful the executive is depends on how successful one expects it to be. These expectations depend on several factors. Based on 
the models presented, the literature (Saiegh 2009; Diermeier and Vlaicu 2011b) identifies variables that take into consideration the conditions under which the executive is operating. The most important ones are the (constant) availability of legislative majorities, the influence and the coherence of the party government of the ruling coalition in the legislature, and the control over the agenda by the executive and the majority.

The highest scores of executive success are expected to occur in Westminster-style parliamentary systems. This special form of parliamentary system features the main characteristics of a concentrated executive power within a strong one-party, majoritarian government and of clear dominance that the executive exercises in unity with the governing party over the legislature and the legislative process, inter alia facilitated by the far-reaching agenda-setting power it holds in the standing orders (Döring 1991).

Taking this into consideration, it is not surprising to find that prime ministers and their cabinets are able to obtain passage of almost all of their pieces of legislation under such conditions. Saiegh (2009) provides evidence for executive success rates in Westminster-style legislators from 90 to 96 percent and thereby confirms the theoretical expectations. However, our data indicate similarly high success-rates for the Länder, even though the executive operates under different and arguably less favorable condition in the context of the subnational parliamentary systems in Germany. One would instead expect the executive success rate to be about 85 percent (Diermeier and Vlaicu 2011b), as at the national level, since the constitutional and legislative institutions at the subnational level are closer to those on the German federal level than to those of a Westminster-style system. The results are surprising, since the governments in German Länder are usually based on more or less heterogeneous multiparty coalitions, which are theoretically and empirically assumed to lead to lower governmental success (Cheibub et al. 2004; Saiegh 2009).

Comparing the success of executives in the German states to the empirical findings of success rates in 14 different parliamentary systems (Saiegh 2009), we find the scores of the Länder to be significantly above the average of 83 percent. How can these exceptional success rates, reaching the level of a Westminster-style system, be explained? What are the mechanisms accounting for the variance of the success rates in the German cases?

\section{Puzzle 2: Why are the executive success rates in some Brazilian states as high as one would expect them to be in a Westminster-style parliamentary system?}

The second puzzle studied in this paper regards the legislative success rate of Brazilian governors. Some of them are as successful in passing their bills throu- gh the legislature as prime ministers in Westminster-style systems. How can this be so, if governors in Brazil have to work with legislatures comprised of many different political parties which are ideologically diverse and if governors, unlike their counterpart at the national level, cannot issue decrees ${ }^{3}$ (Abrucio 1998; Santos 2001; Pereira 2001)?

Much of the literature on the Brazilian political system at the national level explains the high presidential success rate as resulting from a combination of presidential agenda power with a centralized organization for the parliament (Figueiredo and Limongi 2000; Santos 2003; Amorim Neto et al. 2003). We hypothesize, then, that the more centralized the state assemblies are, the more likely it will be for the corresponding governors to reach a very high success rate for their bills, comparable to Westminster-style parliaments.

Finally, the third puzzle is: How can governors belonging to presidential and parliamentary systems have essentially the same success rate for their bills? If the constitutional rules governing the systems are so different, and Brazilian governors do not have the same constitutional mechanisms (namely the vote of confidence) to hold coalitions together, then we expect legislative organization to explain at least some of the similarity between Brazilian and German governors.

\section{(III) Explaining the puzzles through legislative mechanisms}

In order to address the puzzles presented above, we develop an analytical framework, focusing on legislative rules within the standing orders of the subnational assemblies. While most literature is focused on the 'basic' institutions, laid down in the constitutions and electoral laws, all three presented models inherently also address these 'minor' legislative rules as well, since they can have considerable impacts on policymakers and outcomes. Particularly, recent studies on positive and negative agenda-setting power (Cox 2000; 2006) highlight the relevance of standing orders to understand the relationship between parties, governing coalitions and legislators within the institutional context of the assemblies in a comprehensive manner.

Our analytical framework is based on theoretical assumptions derived from the three main models outlined above. It is composed of three main and interlinked areas. The first one addresses the committee organization, composition and competences and the restrictions that are attributed to the entities within the legislative process.

The items exploring these issues are based on insights gained from the informational model (Gilligan and Krehbiel 1990) and items that have already been applied in are often cited, as set out in the comparative study of Döring (1995). The role of committees 
in legislative organization is crucial to understand the institutional centralization or decentralization of power and the relationship between the parties, plenary and committees. According to the informational approach, the majority group of legislators rather than party coalitions controls the institutional organization and thus has the choice to centralize or not to centralize power in the hands of some (partisan) leaders. Secondly, and more important in this context, legislators cannot be sure about the policy outcomes of the legislation. However, a committee system, facilitating the policy specialization of legislators (Arbeitsparlament), mitigates the assumed uncertainty dilemma that rational legislators face. The members of committees acquire special knowledge and can provide other legislators with information and thereby yield added value to the whole legislature. Krehbiel (1998) argues that committees are not autonomous entities but rather are representative ones, supplying information and reducing uncertainty about proposed bills. In terms of representation, they can however represent the whole assembly (vis-à-vis the government) or act as partisan representatives.

If committee members and committee leaders are chosen by party caucuses (Item 1 and 2), then power is more centralized in the hands of the parties and party leaders and the ideological representation of committees as entities of the whole can be undermined. Or as Döring $(1995,275)$ puts it, parties can indirectly control the long-range policy positions in the legislatures by controlling the assignment of committee memberships and chairs. This implies the assumption that more centralized committees can increase the legislative success of the governing parties, since the entities are under the influence of party leaders, with the offices in the committees depending on them. Further, we investigate the competences of the committees in the legislative process (items 1 to 5 ). The power attributed to committees is supposed to have an impact on the committees' ability to influence policy outputs and to shape their position and independence vis-à-vis the majorities in the chamber and the government. In this context, Krehbiel (1988) introduces the concept of positive and negative committee power. While the first enables the committee to influence change, the second enables the entities to preserve the status quo. The ability of committees to unilaterally kill or approve a bill (item 3 and 4) makes the entities more independent towards majorities on the floor and reflects their competence to act and to decide on behalf of the whole chamber through the positive and negative committee power attributed to them. Moreover, the existence or lack of a time limit for the debating bills before they are submitted to the floor constitutes another factor of the power attributed to committees (item 5). Without any time limit, they are free to block bills and the legislative process in order to preserve the status quo, while a time limit forces them to vote on the bills and deprives them of a way to exert negative committee power. Based on this, it is assumed that weaker positive and negative committee powers reduce the independence of committees as representatives of the whole house and favors the success of governing parties and party leaders in legislation. Finally, the last item in this section focuses on the ability of the plenary to amend bills that have been already approved in committee. This reduces the positive and negative committee power and their independence in decision-making. It makes committee members more sensitive to majorities on the floor, whether they are unstable as predicted by the informational and distributive model, or stable due to partisan alignment of legislators in their voting behavior, as is assumed by the two other models.

With respect to the second aspect, we first investigate the role of leaders, steering committees and speakers and the indication of institutional centralization the standing orders provide in this context. The theoretical model that guides our analytical framework in this matter is the 'Procedural Cartel Theory' (Cox 2000; Cox and McCubbins 2005), which shifts the focus from committees - presumed to act as agents of parties rather than as representatives of the whole house- to political parties. Since the cartel of the governmental majority is based on the use of the procedural rule-making power of the chamber, we address the agenda-setting power of the assumedly powerful legislative agenda setting offices defined by Cox $(2006,145)$ - speaker, party leaders, steering committee -, their centralization and the degree to which the parties can control them.

The question arises as to whether party leaders have agenda-setting prerogatives that enable them to place bills on the agenda, or to prevent bills -e.g., of the minority- from reaching the floor. While the 'Procedural Cartel Theory' assumes that positive and negative agenda-setting power for the majority is always present, its concrete nature varies and implies different legislative results and success rates. In order to reveal the agenda-setting power, we investigate to how many office institutions the powers and privileges are attributed (item 6). The more the majority parties can control the agenda through fewer institutions in a coherent manner, the more the model predicts legislative success and/ or the avoidance of negative legislative results for the parties forming the majority. Due to the crucial importance of this item for the agenda setting and consequently for the legislative process, we have decided to weight it double.

However, Cox and McCubbins (2005) acknowledge that the degree to which party members and leaders agree on the party's collective reputation influences the correlation of the agenda-setting powers and legislative outcomes. The related mechanism in item 9 highlights the existence or absence of the negative agenda-setting power of the committees to hold bills back from the floor votes, as is often observed in the case of the United States Congress. This is linked to the urgency regime, which centralizes power in the hands of party leaders and weakens com- 
mittee powers, since it enables leaders to take bills out of committee and to put them to a floor vote immediately. Such urgency regimes exist, for example, in Brazil and Chile (Amorim Neto et al. 2003, pp. 258-259) and can help explain legislative success by the positive agenda-setting power of party leaders. However, it is necessary to investigate the relationship between the negative agenda-setting power of committees and the positive-agenda-setting power of party leaders and the full legislature in detail in order to decide on the degree of centralization in this matter.

In a last aspect, we focus on the floor procedure and more particularly on one item, derived from the 'Conditional Party Government-Model' (Rhode 1991): the floor procedure to split proposed bills and to only vote on specific parts of them ('destaque para votação em separado' in Portuguese). The model predicts partisan aligned voting behavior to be the result of distributive intra-party negotiations and offered incentives, often in the form of 'omnibus bills'. Thereby, the party leaders are able to broker deals among legislators, enabling them to overcome intra-party opposition by offering sufficient 'carrots' and/or 'sticks' in return. The procedure to vote separately on specific parts of a bill can expose these deals and equilibriums inherent in the bill and therefore decreases the agenda-setting power of governing party leaders vis-à-vis single legislators. At the same time, its exposes composed legislation is a sharp instrument in the hands of the opposition. This is particularly true if one thinks of coalition governments with little ideological homogeneity. Thus, it is important to analyze the requirements, laid down in the standing orders, to request and achieve this voting procedure on the floor, which is an indicator of decentralization of the legislative process and potentially decreases the legislative success of governing parties.

We believe that the mechanism explained here can contribute to answer our guiding questions: How can we explain the exceptionally high success rates in some of Brazilian and all of German states, reaching the levels of those of Westminster-style systems? What are the explanations accounting for the variance of the success rates in the Brazilian and German cases at the subnational level and between the subnational and the federal level?

\section{(IV) Results}

\section{The German cases}

Our analysis shows that the basic legislative institutions in the German Länder hardly vary in the sections on the agenda-setting power and on the floor voting procedures and that they are centralized in both aspects to a high degree. The agenda setting is usually dominated by party leaders within the steering committees, as is the case at the federal level
(Chandler et al. 2003). The Councils of Elders, the committees that control the legislative agenda setting and procedures, are proportionally composed of party leaders in all the German cases. So the ability to control the agenda is given and can be used, as it is the case in the Bundestag.

As Chandler et al. $(2011,28)$ points out, governmental parties control the agenda in Germany due to three reasons: i) they hold the majority of seats in committees and the Council of Elders; ii) the Council of Elders allows the majority to control the substantive content of bills, while the rights of the opposition to criticize proposals are guaranteed on the basis of consensus; and iii) once established, the agenda of the Council of Elders can only be contested by majority vote on the floor. Thus the governing coalition partners can implement any agreement they reach among themselves on what will and will not appear on the agenda. While party leaders thereby hold positive and negative agenda-setting power, the speaker, as the head of the assembly, is reduced to a formal, rather marginal function and follows the decisions of the German steering committees on the agenda and voting procedures. But contrary to the Brazilian case, the governmental agenda setters do not have the urgency-regime mechanism in order to take bills out of committee and to influence and hasten the legislative process further. However, this does not imply negative agenda-setting power of committees vis-à-vis parties, since the party caucuses are able to demand submission to the floor in almost all German Länder (except Bavaria).

As far as the voting procedures on the floor are concerned, the splitting of bills is usually possible, if is demanded by a low threshold of legislators on the floor (usually 5 percent), and if it is supported by a simple majority. While this - according to the 'Conditional Party Government-Model' - can decrease the agenda control of the governing coalitions, since it exposes coalition trade-offs and the bill's potentially unpopular parts to separate voting, the requirement of the simple majority enables the governing party coalition to avoid this procedure. For heterogeneous coalitions, the mechanism can still constitute a serious threat and reduce its legislative success.

The most variation with regard to the degree of centralization of basic legislative organization institutions exists in the mechanisms concerning committee organization, composition and competences and restrictions attributed to entities within the legislative process. While in the standing orders of four states (Bavaria, Nordrhein-Westfalen, Sachsen, Thüringen), all tested mechanisms indicate centralization in the hands of the parties, significantly more committee powers are attributed to the legislative entities in Baden-Wuertemberg and Hamburg (committees can unilaterally kill and approve bills and/or have no time limits to analyze them). However, we find no clear indication of an association between this variance and the legislati- 
ve success rates, since very centralized states such as Thüringen and Sachsen feature some of the lowest success rates during specific legislative periods, while Hamburg as a less centralized Land scores consistently high. ${ }^{4}$

Overall, the success rates in the German cases are surprisingly high and the variance rather low. The average success rate of the 45 legislatures that we have investigated is above 97 percent and therefore much higher than the two baselines of Saiegh (2009) (83 percent) and the empirical data regarding the federal level (around 85 percent) suggest (Diermeier and Vlaicu 2011b). As a matter of fact, all success rates during the investigated period constantly lie above 93 percent and reach in eleven cases the top score of 100 percent. The only exception is the lower success rate of the government in Saarland during one legislative period (87 percent).

Compared to the federal Bundestag, the degree of centralization at the subnational level is very similar to most Länder. The agenda setting and floor voting procedure patterns in the states mirror the federal level perfectly. In terms of organization, composition, competences and restrictions, the committees of the Bundestag resemble those in Brandenburg, Berlin, Bremen, Niedersachsen and Schleswig-Holstein, since the entities cannot kill or approve bills unilaterally and have no time limit to debate bills.

\section{Explaining the results in the German cases}

As far as the comparison to the basic institutions at the federal level are concerned, neither the electoral systems nor the coalition composition can account for the difference in the success rates on the subnational and federal level. The mixed election systems of most Länder resemble the federal one, consisting of personalized proportional representation systems (Eder and Magin 2008; Masicotte 2010). Moreover, neither the partisan composition nor the number of governing coalition parties alone can serve as explanation for the difference in the success rates between both levels. The governing coalitions in the Länder are often equal to the ones at the federal level and most of the existing party systems are similar (see Mielke and Reutter 2004; Schniewind 2008). Instead, the most appropriate explanation for the significantly higher success rates of governing coalitions in the Länder lies in the fact that most bills not only need to be approved by the Bundestag, but also by the Bundesrat, which is the federal representation of the Länder. It extends party politics by the federal conflict dimension between the Bund and the Länder and the leads to the possibility of a divided government (Rudzio 2003, Patzelt 2004). This complicates the legislative process and explains why the success rates of centralized legislatures at both levels are so different under similar conditions (election system, composition of coalitions and party systems).
With regard to the variance in the legislative success rates of governments and governmental coalitions in the Länder from 1990-2010, we have already pointed to the fact that according to our data, the degree of centralization cannot provide a sufficient explanation, nor do election systems. The dominant literature still focuses on government coalitions and ideological conflict to explain success rates in parliamentary systems (Cheibub et al. 2004; Saiegh 2009, Bräuniger and Debus 2009). Arguably, single party governments should obtain higher legislative success rates, while multiparty government coalitions comprise more players in the form of governmental leaders with veto powers, especially when heterogeneity in the coalition is high (Saiegh 2009, p. 1350). For the German cases, we can rely on the spectrum of polarization of party governments according to a classic right-left scheme in order to check this finding for the Länder (Schniewind 2008).

We find that in 12 out of 15 cases of a single-party government, the success rate is above the average of 97 percent. Besides this, the multiparty coalitions in the Länder have in common only two parties, with one exception of a three-party governing coalition in Hamburg (from 2001-2004, with a success rate of 97 percent). However, in this group we find no indication of a considerable impact of polarization of coalition partners on the success rates. More polarized coalition compositions, such as the combination SPD/FDP or CDU/Grüne, do not score significantly lower as the literature on coalitions and legislative success suggests should be the case.

Altogether, our analysis does not prove the hypothesis that a higher degree of centralization of the basic legislative rules leads to higher legislative success of the governments in the case of the Länder. Instead, we can explain the higher legislative success at the subnational level by the absence of an institution like the Bundesrat. The only indication we find with regard to the puzzle of the variation between the states and different legislative periods is the distinction between single-party governments and two-party governments, since single-party governments score higher.

\section{The Brazilian cases and preliminary explanations for the results}

The 27 Brazilian state assemblies average 7.48 out of 10 on our legislative centralization index. Their committee systems - with the exception of Paraíba, Rio Grande do Norte and Rio Grande do Sul are somewhat toothless. A typical example is Mato Grosso do Sul, where committee members are chosen by party caucuses according to proportionality; committee chairs are elected by committee members; committees are powerless both to unilaterally approve and kill bills, and there is a time limit to analyze bills before they go to the floor. This institutional design is compounded by the fact that all governors may attach the "urgency regime" to 
most of their bills, making the committee system even more irrelevant. Our expectation is that the less powerful the committee system is, the easier (and quicker) it is for a governor to pass bills throu$\mathrm{gh}$ the legislature.

There is more interesting variation regarding agenda-setting institutions in the assemblies. In 18 states, only one institution or person (usually the speaker) concentrates both positive and negative agenda power. We expect these assemblies to be associated with higher legislative success rates for the governor, since he or she would have to deal with less veto players than is usual in Brazil's political system.

Regarding the three items related to the plenary, there is no variation in the 27 Brazilian states. In all assemblies, the full legislature can amend bills passed by committees (though the threshold for this varies somewhat); the plenary can divide bills and vote on specific parts of them and the "urgency regime" procedure - which allows the plenary to vote on bills that were examined in committee - exists.

Our empirical basis is the dataset assembled by Ricci and Tomio (2010), in which they assess the legislative success rate of 17 Brazilian governors from 1994 to 2008. There are 61 observations. In about half (34/61) there are very centralized assemblies (ranking 8 or higher in our centralization index). In 32 of 61 observations of Brazilian state assemblies, governors have a success rate higher than 90 percent, which is very Westminster-like. Nineteen of the observations occur in very centralized assemblies and 13 in somewhat centralized assemblies. This is in line with earlier works on the state assemblies in Brazil, most notably Abrucio (1998), although he does not focus on legislative organization as an explanatory variable for governors' success.

In the São Paulo state assembly (Alesp), like in many others, governors can resort to negotiations with the speaker, who is empowered to appoint a "Special Rapporteur" (Relator Especial) to substitute committee reports. This mechanism is frequently used to fast-track government bills. ${ }^{5}$ Therefore, one must not ignore the importance of minor legislative institutions in the agenda setting and success rate of Brazilian governors.

Table 1 shows how the state assemblies fare according to the Saiegh (2009) baseline for executive success in presidential multiparty systems (Brazil) and parliamentary multiparty systems (Germany) and also the federal level baseline for executive success in both countries.

Table 3. Governors' success rate in Brazilian States (1994-2008) and German States (1990-2010)

\begin{tabular}{lccc}
\hline & $\begin{array}{c}\text { Higher success } \\
\text { than Saiegh (2009) } \\
\text { baseline? }\end{array}$ & $\begin{array}{c}\text { Higher success } \\
\text { than federal } \\
\text { level baseline? }\end{array}$ & $\begin{array}{c}\text { More than } \\
90 \% \text { success? }\end{array}$ \\
\hline $\begin{array}{l}\text { Very centralized assemblies } \\
\text { Somewhat centralized }\end{array}$ & $96 \%(70 / 73)$ & $93 \%(68 / 73)$ & $78 \%(57 / 73)$ \\
\hline Total & $97 \%(30 / 31)$ & $90 \%(28 / 31)$ & $55 \%(17 / 31)$ \\
\hline
\end{tabular}

Sources: Authors' calculations based on Ricci and Tomio (2010), Saiegh (2009) and Brazilian state assemblies' standing orders.

Some tentative conclusions based on Table 3 are in order:

I) Governors' success rates in both Brazil and Germany seem not to be associated with centralization of legislative institutions. This means that coalition management and party politics may play a bigger role than expected by some of the literature.

II) Minor legislative institutions - such as the appointment of Special Rapporteurs in some Brazilian cases - can compound the governors' strength and allow them to reach Westminster levels of legislative success.

III) Legislative mechanisms associated with the workings of the full legislature may be important in defining the content of legislation (Heller 2001) and some policy outcomes (Rasch 2000), but they do not seem relevant for the success rate of the executive.
IV) The analysis of the agenda-setting power should be extended by further research on coalitions and their policy agreements. The number of coalition partners and the degree of ideological homogeneity or heterogeneity might influence legislative success, as a large part of the literature already notes.

V) The policy content of bills influences the probability of executive success (Gamm and Kousser 2010) and therefore should be taken into consideration. 


\section{References}

ABRUCI0, Fernando (1998) ‘0 ultrapresidencialismo estadual', In: ANDRADE, Régis (Ed.) Processo de Governo no Município e no Estado. São Paulo: Edusp.

AMORIM NETO, Octavio \& COX, Gary W. \& MCCUBBINS, Mathew (2003), 'Agenda Power in Brazil's Câmara dos Deputados, 1989-98'. In: World Politics, 55 pp. 550-578.

ARNDT, Christoph (1989)'Fraktion und Abgeordneter'. In: Schneider, Hans-Peter \& Zeh, Wolfgang (Eds.) Parlamentsrecht und Parlamentspraxis in der Bundesrepublik Deutschland. Berlin: Walter de Gruyter.

BRAGA, Maria do Socorro \& PRAÇA, Sérgio. (2007) ‘Recrutamento partidário: seleção de candidatos à Câmara paulistana'. In: KINZO, Maria D’Alva \& BRAGA, Maria do Socorro. (Eds.) Eleitores e representação partidária no Brasil. São Paulo: Humanitas, pp. 179-203.

BRÄUNINGER, Thomas \& DEBUS, Marc (2009) 'Legislative agenda-setting in parliamentary democracies'. In: European Journal of Political Research, 48 (6), pp. 804-839.

BRÄUNINGER, Thomas \& GANGHOF, Steffen (2005) In: GANGHOF, Steffen. \& MANOW, Philip (Eds.) Mechanismen der Politik. Strategische Interaktion im deutschen Regierungssystem. Frankfurt/New York: Campus Verlag, pp. 35-72.

CAMERON, Charles. (2000), Veto Bargaining: Presidents and the Politics of Negative Power. New York, Cambridge University Press.

CAREY, John \& SHUGART, Matthew (1995) “Incentives to cultivate a personal vote: a rank ordering of electoral formulas". In: Electoral Studies, 4 (4), pp. 417-439.

Carey, John \& Shugart, Matthew (1998) Executive decree authority. New York, Cambridge University Press.

CHANDLER, William; COX, Gary \& MCCUBBINS, Mathew (2011) 'Agenda Control in the Bundestag 1980-2002'. In: German Politics, 15 (1), pp. 27-48.

CHEIBUB, Jose Antonio; PRZEWORSKI, Adam and SEBASTIAN, Saiegh. (2004). 'Government Coalitions and Legislative Success under Presidentialism and Parliamentarism'. In: British Journal of Political Science, 34 (4), pp. 565-587.

COWLEY, Philip (2002) Revolts and Rebellions: Parliamentary Voting Under Blair. London: Politicos.

COX, Gary (1987) The Efficient Secret. New York, Cambridge University Press.

COX, Gary (2000) 'On the effects of legislative rules'. In: Legislative Studies Quarterly, 25 (2), pp. 169-192.

COX, Gary \& MCCUBBINS Mathew (2005) Setting the Agenda: Responsible Party Government in the U.S. House of Representatives. New York: Cambridge University Press.

COX, Gary (2006) ‘The organization of democratic legislatures'. In: Weingast, Barry \& Wittman, Donald. The Oxford Handbook of Political Economy. 0xford: Oxford University Press, pp. 141-161.

DIERMEIER, Daniel \& Vlaicu, RAZVAN (2011a) 'Parties, Coalitions, and the Internal Organization of Legislatures'. In: American Political Science Review, 105 (2), pp. 359-380.

DIERMEIER, Daniel \& VLAICU, Razvan (2011b) 'Executive Control and Legislative Success'. In: Review of Economic Studies, March, pp. 1-26.

DÖRING, Herbert (1991) ‘Präsidentialisierung des parlamentarischen Systems? Westminster und Whitehall in der Ära Thatcher'. In: Aus Politik und Zeitgeschichte, 28.

DÖRING, Herbert (1995) ‘Parliaments and Majority Rule in Western Europe' Frankfurt/New York: Campus Verlag.

DÖRING, Herbert. "Parliamentary agenda control and legislative outcomes in Western Europe”, Legislative Studies Quarterly, 26 (1) pp. 145-165.

DÖRING, Herbert, \& MARK Hallerberg (2004) Patterns of Parliamentary Behaviour: Passage of Legislation across Western Europe. Aldershot: Ashgate Publishing Limited.

EDER, Christina \& MAGIN, Raphael (2008) '2. Wahlsysteme'. In: Freitag, Markus \& Vatter, Adrian (Eds.) Die Demokratien der deutschen Bundesländer. Opladen/Farmington Hills: Verlag Barbara Budrich, pp. 33-62.

FIGUEIRED0, Argelina \& LIMONGI, Fernando (2000) 'Presidential power, legislative organization, and party behavior in Brazil', Comparative Politics, 32 (2), pp. 151-170.

GAMM, Gerald \& KOUSSER, Thad (2010) ‘Broad bills or particularistic policy? Historical patterns in American State Legislatures'. In: American Political Science Review, 104, (1), pp. 151-170.

GILLIGAN, Thomas \& KREHBIEL, Keith (1987a)'Collective decision-making and standing committees'. In: Journal of Law and Economic Organisation, 3, pp. 287-335.

GILLIGAN, Thomas \& KREHBIEL, Keith (1987b) ‘Collective choice without procedural commitment'. In: Ordeshookm Peter (Ed.) Models of Strategic Choice in Politics, Ann Arbor: University of Michigan Press, pp. 295-314..

GILLIGAN, Thomas \& KREHBIEL, Keith. (1990) 'Organization of informative committees in a rational legislature.' In: American Journal of Political Science, 34, pp. 531-64.

HELLER, William (2001) 'Making policy stick: why the government gets what it wants in multiparty parliaments', American Journal of Political Science, 45 (4), pp. 780-798.

KREHBIEL, Keith (1988) 'Spatial Models of Legislative Choice'. In: Legislative Studies Quarterly, 13 (3),pp. $259-319$.

KREHBIEL, Keith (1993a) 'Party discipline and measures of partisanship'. In: American Journal of Political Science, 44, pp. 212-227,

KREHBIEL, Keith(1993b) ‘Where's the Party?’. In: British Journal of Political Science, 23, pp. 235-266.

KREHBIEL, Keith (1995) 'Cosponsors and Wafflers from A to Z.'. In: AmericanJournal of Political Science, 39, pp. 906-923. 
KREHBIEL, Keith (1998) Pivotal Politics: A Theory of U.S. Lawmaking. Chicago: University of Chicago Press.

MAINWARING, Scott (1991) 'Politicians, Parties, and Electoral Systems: Brazil in Comparative Perspective.' In: Comparative Politics, October, pp. 21-43.

MAINWARING, Scott \& SHUGART, Matthew (1997) Presidentialism and Democracy in Latin America. Cambridge, Cambridge University Press.

MASSICOTTE, Luise (2003) ‘To create or to copy? Electoral Sytems in the German Länder.' In: German Politics, 12, pp. 1-22.

MCCARTY, Nolan \& POOLE, Keith \& ROSENTHAL, Howard (2001) The hunt for party discipline. In: American Political Science Review, 95, pp. 673-688.

MCCUBBINS, Mathew (2005) 'Legislative Process and the Mirroring Principle'. In: MÉNARD, Claude and SHIRLEY, Mary. (Eds.) Handbook of New Institutional Economics, Dordrecht et al.: Springer, pp. 123-147

MENG, Richard (2002) Der Medienkanzler: Was bleibt vom System Schröder? Frankfurt a.M.: Suhrkamp.

MIELKE, Siegfried and REUTTER, Werner (2006) Länderparlamentarismus in Deutschland. Geschichte - Struktur Funktionen.Wiesbaden: Verlag für Sozialwissenschaften.

NETO, Octavio \& COX, Gary and McCubbins, Methew (2003) 'Agenda Power in Brazil's Câmara dos Deputados, 1989-1999'. In: World Politics, 55 (July), pp. 550-578.

PATZELT, Werner (2004) 'Chancellor Schroöder's Approach to Political and Legislative Leadership'. In: German Politics, 13, pp. 268-299.

PEREIRA, André Ricardo (2001). 'Sob a ótica da delegação: governadores e assembléias no Brasil pós-1989_, in SANTOS, Fabiano. (Ed.) 0 Poder Legislativo nos Estados: diversidade e convergência. Rio de Janeiro: Ed. FGV, pp. 247-287.

RASCH, Bjorn E. (2000) 'Parliamentary floor voting procedures and agenda setting in Europe'. In: Legislative Studies Quarterly, 25, (1), pp. 3-23.

RICCI, Paolo \& TOMIO, Fabricio (2010) 'Instituições e decisões: estudo comparativo do processo legislativo nas Assembleias Estaduais'. In: Texto apresentado no $7^{\circ}$ Encontro da Associação Brasileira de Ciência Política, Recife.

ROHDE, David (1991) Parties and Leaders in the Postreform House. Chicago: Univ. Chicago Press

RUDZIO, Wolfgang (2003) Das politische System der Bundesrepublik Deutschland. Opladen: UTB Leske + Budrich.

SAALFELD, Thomas (2005) 'Determinanten der Fraktionsdisziplin: Deutschland iminternationalenVergleich'. In: GANGHOF, Steffen. \& MANOW, Philip (Eds.) Mechanismen der Politik. Strategische Interaktion im deutschen Regierungssystem. Frankfurt/New York: Campus Verlag, pp. 35-72.

SAIEGH, Sebastian (2009) 'Political Prowess or "Lady Luck"? Evaluating Chief Executives' Legislative Success Rates'. In: The Journal of Politics, 71 (4), pp. 1342-1356.

SANTOS, Fabiano (2001) 0 poder legislativo nos estados: diversidade e convergência. Rio de Janeiro: Ed. FGV

SANTOS, Fabiano (2003) 0 Poder Legislativo no Presidencialismo de Coalizão, Ed. UFMG/IUPERJ.

SCHNIEWIND, Aline (2008) '4. Regierungen'. In: Freitag, Markus \& Vatter, Adrian (Eds.) Die Demokratien der deutschenBundesländer. Opladen/Farmington Hills: Verlag BarbaraBudrich, pp. 111-160.

SNYDER, James \& GROSECLOSE, Timothy (2000) 'Estimating party influence in congressional roll call voting'. In: American Journal for Political Science, 44, pp. 193-211.

STROM, Kaare (1998) 'Parliamentary committees in European democracies", Journal of Legislative Studies, 4 (1), pp. 21-59.

STRÖM, Kaare \& MÜLLER, Wolfgang \& SMITH, Daniel M. (2010) ‘Parliamentary control of coalition governments'. In: Annual Review of Political Science, 13, pp. 517-535.

\section{Notas}

1 Diermeier and Vlaicu (2011b) is a recent exception.

2 The empirical finding of regular legislative voting-behavior along party lines does not represent a refutation of the model, since the observations might simply capture aggregate preferences that correlate with partisan membership. Taking this perspective, they do not provide convincing evidence for 'party influence'.

3 With the exception of four states.

4 Unfortunately, the data for three German states are not publicly available or were not provided as we requested from the assembly research services (Baden-Wuertemberg, Berlin and Bremen).

5 Interviews with São Paulo deputies and Alesp staff carried out by us and research assistant Thiago Belmar in the first half of 2011 support this. 